\title{
PENGARUH KOMUNIKASI ANTAR PRIBADI DAN ETIKA KOMUNIKASI KEPALA SEKOLAH TERHADAP LOYALITAS GURU SMP MAITREYAWIRA BATAM
}

\author{
THE EFFECT OF INTER-PERSONAL COMMUNICATION AND SCHOOL HEAD OF \\ COMMUNICATION ETHICS ON TEACHER LOYALTY OF MAITREYAWIRA BATAM \\ MIDDLE SCHOOL
}

\author{
Ivonne Setiawati ${ }^{1}$, Nasruji ${ }^{2}$ \\ Program Studi Magister Manajemen Program Pascasarjana Universitas Riau Kepulauan ${ }^{1}$ \\ FKIP Universitas Riau Kepulauan ${ }^{2}$ \\ ivonnesetiawati@gmail.com
}

\begin{abstract}
Abstrak
Penelitian ini bertujuan untuk mengungkap pengaruh komunikasi antarpribadi dan etika komunikasi kepala sekolah terhadap loyalitas guru di SMP Maitreyawira Batam. Permasalahan dalam penelitian ini adalah bagaimana pengaruh komunikasi antarpribadi dan etika komunikasi kepala sekolah terhadap loyalitas guru? Populasi dalam penelitian ini adalah kepala sekolah dan guru di SMP Maitreyawira Batam sebanyak 25 orang. Pengambilan data dilakukan dengan cara menyebarkan kuesioner penelitian kepada responden di lokasi penelitian. Data yang diperoleh dianalisis menggunakan uji regresi linier berganda. Hasil penelitian menunjukan bahwa komunikasi antarpribadi (X1) dan etika komunikasi kepala sekolah (X2) secara simultan memiliki hubungan signifikan terhadap loyalitas guru (Y) sebesar 5,9\%. Oleh karena itu dapat disimpulkan bahwa komunikasi antarpribadi dan etika komunikasi kepala sekolah secara bersama-sama tidak berpengaruh terhadap loyalitas guru.
\end{abstract}

Kata Kunci: Komunikasi Antar Pribadi, Etika Komunikasi, Loyalitas Guru

\begin{abstract}
This research aims to reveal the influence of interpersonal communication and communication ethics of the principal towards teacher loyalty in Maitreyawira Batam Junior High School. The focus problem in this research is how can interpersonal communication and communication ethics of principal influence teacher loyalty? Population in this research is principal and teacher in Maitreyawira Batam Junior High School to the tune of 25 people. The data were collected by distributing the research questionnaires to the respondents in the research location. The data obtained were analyzed using multiple linear regression test. The results showed that interpersonal communication (X1) and principal communication ethic (X2) simultaneously have significant relationship to teacher's loyalty $(Y)$ of $5.9 \%$. Therefore it can be concluded that interpersonal communication and communication ethics principal together not affect the teacher's loyalty.
\end{abstract}

Keywords: Interpersonal Communication, Communication Ethics, Teacher Loyalty

\section{PENDAHULUAN}

Dalam Undang-Undang Nomor 20 tahun 2003, definisi pendidikan merupakan usaha sadar dan terencana untuk mewujudkan suasana belajar dan proses pembelajaran agar peserta didik secara aktif mengembangkan potensi dirinya untuk memiliki kekuatan spiritual keagamaan, pengendalian diri, kepribadian, kecerdasan, akhlak mulia, serta keterampilan yang diperlukan dirinya, masyarakat, bangsa dan negara. Sebuah usaha pada dasarnya didasari oleh kesadaran, kesadaran akan apa yang ingin dilakukan dan dicapai. Usaha sadar 
ini membutuhkan komitmen dan konsistensi dari para guru untuk menghasilkan lulusanlulusan yang berguna bagi bangsa dan negara. Komitmen dan konsistensi ini dapat dikembangkan jika guru memiliki loyalitas yang baik terhadap sekolah.

\section{Tujuan Penelitian}

1. Untuk mengetahui dan menguji apakah faktor komunikasi antarpribadi berpengaruh terhadap loyalitas guru di SMP Maitreyawira Batam.

2. Untuk mengetahui dan menguji apakah faktor etika komunikasi kepala sekolah berpengaruh terhadap loyalitas guru di SMP Maitreyawira Batam.

\section{Tinjauan Pustaka}

Loyalitas memiliki kata dasar loyal yang berasal dari bahasa Perancis kuno, loial yang berarti setia atau patuh (Poerwadarminta, 2012:609), atau secara umum loyalitas dapat diartikan sebagai bentuk kesetiaan. Bentuk kesetiaan ini bagi profesi guru merupakan bentuk kesetiaan terhadap profesinya sebagai guru, sekolah, dan peserta didiknya. Loyalitas yang baik dapat tumbuh dari komunikasi yang baik di lingkungan kerja terutama dari atasan.

Kepala sekolah sebagai pemimpin di sekolah harus memiliki kemampuan berkomunikasi yang baik. Menurut Robbins dan Judge (2008:49), kepemimpinan dapat didefinisikan sebagai kemampuan untuk mempengaruhi suatu kelompok guna mencapai sebuah visi atau serangkaian tujuan yang ditetapkan. Salah satu definisi komunikasi menurut Scheidel, manusia pada umumnya berkomunikasi untuk menyatakan dan mendukung identitas diri dan untuk membangun interaksi sosial dengan orang-orang yang berada di sekitar kita serta untuk mempengaruhi orang lain untuk berpikir, merasa, atau bertingkah seperti yang kita harapkan.

Komunikasi antar pribadi yang efektif dapat membangun dan meningkatkan loyalitas guru. Menurut Nina (2009), menyatakan ada hubungan antara komunikasi dengan loyalitas karyawan, jika komunikasi terbentuk secara positif maka loyalitas akan tinggi. Sedangkan cara kita berkomunikasi atau menyampaikan pesan juga merupakan hal yang penting.

Etika komunikasi merupakan norma, nilai, atau ukuran sesuatu yang baik dalam kegiatan berkomunikasi. Menyampaikan pesan atau berkomunikasi tanpa mengetahui etikanya bisa mengakibatkan lawan bicara merasa tidak nyaman bahkan tersinggung. Sebaliknya, ketika berkomunikasi dengan menggunakan etika yang baik maka bisa membuat nyaman dan lawan bicara kita merasa dihargai. Karyawan hanya akan loyal terhadap perusahaan tempatnya bekerja jika menemuan rasa aman dan nyaman. 


\section{METODOLOGI}

\section{Rancangan Penelitian}

Jenis penelitian ini adalah penelitian yang bermaksud menjelaskan Penelitian ini menggunakan metode deskriptif kuantitatif karena penelitian ini menjelaskan hubungan antar komunikasi antarpribadi dan etika komunikasi dengan menganalisis data numerik (angka) menggunakan metode statistik melalui pengujian hipotesa yang mempengaruhi loyalitas guru di SMP Maitreyawira Batam berdasarkan data kuisioner.

\section{Hipotesis Penelitian}

Dalam Pokok-Pokok Materi Metodologi Penelitian dan Aplikasinya (Hasan, 2002:50) tertulis bahwa: "Hipotesis adalah jawaban yang bersifat sementara terhadap masalah penelitian yang kebenarannya masih lemah, sehingga harus diuji secara empiris (hipotesis berasal dari kata "hypo" yang berarti di bawah dan "thesa" yang berarti kebenaran)."

Hipotesis adalah dugaan sementara atau jawaban sementara atas permasalahan penelitian dimana memerlukan data untuk menguji kebenaran dugaan tersebut (Kountur, 2015:93).

Berdasarkan latar belakang masalah, identifikasi masalah, batasan masalah, rumusan masalah, tujuan, kegunaan penelitian, penulis membuat hipotesis sebagai berikut:

1. Ho: Komunikasi antar pribadi dan etika komunikasi kepala sekolah tidak berpengaruh terhadap loyalitas guru di SMP Maitreyawira Batam.

2. $\mathrm{H}_{1}$ : Komunikasi antarpribadi dan etika komunikasi kepala sekolah berpengaruh terhadap loyalitas guru di SMP Maitreyawira Batam.

\section{Populasi, Sampel, Besar Sampel, dan Penarikan Sampel Populasi}

Penelitian ini memerlukan obyek atau subyek yang menjadi kuantitas dan karakteristik tertentu yang ditetapkan oleh peneliti untuk dipelajari dan kemudian ditarik kesimpulannya. Oleh karena itu, penelitian ini meneliti semua guru SMP Maitreyawira Batam yang berjumlah 25 orang.

\section{Sampel}

Penelitian ini populasinya homogen (guru), maka penelitian ini adalah penelitian sampel. Menentukan besarnya sampel sebenarnya dapat menggunakan rumus Slovin (Umar, 2003: 120).

$$
\mathrm{n}=\mathrm{N} 1+\mathrm{Ne} 2
$$


dimana:

$$
\begin{array}{ll}
1 & =\text { konstanta } \\
\mathrm{n} & =\text { ukuran sampel } \\
\mathrm{N} & =\text { ukuran populasi } \\
\mathrm{e}^{2} & =\text { kelonggaran ketidaktelitian karena kesalahan pengambilan sampel yang dapat } \\
\text { ditolerir } &
\end{array}
$$

$$
\mathrm{n}=251+25(0,05) 2=23,5 \approx 24
$$

\section{Variabel Penelitian}

Permasalahan yang diangkat pada penelitian ini adalah permasalahan asosiatif, yaitu suatu pertanyaan peneliti yang bersifat menghubungkan dua variabel atau lebih. Hubungan variabel dalam penelitian adalah hubungan kausal, yaitu hubungan yang bersifat sebab-akibat.

Menurut Umar (2013:63) Variabel independent (bebas) adalah variabel yang menjelaskan atau mempengaruhi variabel yang lain, sedangkan variabel dependent (tergantung) adalah variabel yang dijelaskan atau yang dipengaruhi variabel independent. Variabel yang memengaruhi disebut variabel penyebab, variabel bebas atau independent variabel (X), sedangkan variabel akibat disebut variabel tidak bebas atau variabel tergantung, variabel terikat atau dependent variabel (Y). Variabel yang terdapat pada penelitian ini terdiri dari:

1. Variabel bebas $(\mathrm{X})$ yang terdiri dari:

Variabel $\mathrm{X}_{1}$, yaitu komunikasi antarpribadi kepala sekolah dengan guru dengan indikator yang diteliti adalah kuantitas komunikasi secara langsung, status dalam berkomunikasi, dan umpan balik, dengan total enam pernyataan.

Variabel $\mathrm{X}_{2}$, yaitu etika komunikasi kepala sekolah dengan indikator cara penyampaian, memuat motivasi, dan kenyamanan bekerja, dengan total delapan pernyataan.

2. Variabel terikat (Y), yaitu loyalitas guru dengan indikator kesamaan visi misi pribadi dengan lembaga, rasa kepemilikian terhadap lembaga, rasa tanggung jawab, dengan total sembilan pernyataan.

\section{Teknik Analisis Data}

1. Penyeleksian dan Pengklasifikasian Data

Lembar angket yang telah diisi responden diperiksa kelengkapan pengisiannya kemudian disortir, lalu diinputkan dan diklasifikasikan ke dalam tabulasi data 
(Lampiran 1). Dari hasil penyeleksian angket, diperoleh 25 set data angket guru yang layak digunakan.

2. Analisis Deskripsi Karakteristik Responden dan Variabel

Data yang telah ditabulasi kemudian dianalisis sehingga didapatkan deskripsi umum baik dari karakteristik responden penelitian maupun dari variabel penelitian. Analisis karakteristik responden dan variabel dilakukan secara deskriptif kuantitatif bertujuan untuk memberikan gambaran awal mengenai karakteristik responden yang terlibat dan variabel-variabel yang dihipotesiskan.

Analisis deskripsi karakteristik responden dilakukan dengan cara menghitung dan menyajikan jumlah dan persentase tiap-tiap karakteristik responden yakni jenis kelamin, usia, dan tingkat pendidikan terakhir. Analisis data ini dilakukan dengan bantuan piranti lunak Microsoft Excel 2010.

Analisis deskripsi variabel dilakukan dengan cara menghitung dan menyajikan karakteristik kuantitatif tiap variabel yakni ukuran tendensi sentral (rata-rata), ukuran dispersi (standar deviasi), serta distribusi data (kemiringan (skewness) dan keruncingan (kurtosis)). Berbagai deskripsi kuantitatif tersebut akan dihitung dengan bantuan software SPSS 19.0.

3. Uji Hipotesis Penelitian

Uji hipotesis penelitian dilakukan dengan analisis regresi linear dengan bantuan software SPSS 19.0. Pengujian hipotesis menggunakan analisis regresi linear ganda. Untuk menentukan hipotesis nihil $\left(\mathrm{H}_{0}\right)$ diterima atau ditolak digunakan uji signifikansi regresi dan koefisien regresi. Jika pada pengujian signifikansi regresi dan koefisien regresi diperoleh nilai probabilitas pada ouput SPSS kurang dari taraf signifikansi yaitu nilai sig $<0,05$ maka hipotesis nihil diterima.

\section{PEMBAHASAN}

\section{Deskripsi Data}

1. Deskripsi Karakteristik Responden

Sekolah Maitreyawira Batam adalah sebutan umum bagi sekolah swasta, yang terdiri dari satuan pendidikan TK, SD, SMP, dan SMA yang didirikan oleh Yayasan Pancaran Maitri, berlokasi di kota Batam, Kepulauan Riau. Dari hasil pengolahan data penelitian, sebaran responden adalah pendidik SMP Maitreyawira Batam yang berjumlah 25 orang. 
Karakteristik responden penelitian dilihat berdasarkan karakteristik jenis kelamin, usia, tingkat pendidikan terakhir, dan rata-rata masa kerja tersaji sebagai berikut.

a. Deskripsi responden berdasarkan jenis kelamin

Distribusi responden berdasarkan jenis kelamin dapat dilihat pada Tabel 1 dan disajikan dalam bentuk diagram berikut.

\section{Tabel 1}

Distribusi Responden Berdasarkan Jenis Kelamin

\begin{tabular}{ccc}
\hline Jenis Kelamin & Frekuensi & Persentase \\
\hline Laki-Laki & 4 & $16 \%$ \\
Perempuan & 21 & $84 \%$ \\
Total & 25 & $100 \%$ \\
\hline
\end{tabular}

Dari data di atas dapat disimpulkan responden dengan jenis kelamin perempuan lebih dominan.

b. Deskripsi responden berdasarkan usia

Distribusi responden berdasarkan usia dapat dilihat pada Tabel 2 dan disajikan dalam bentuk diagram berikut.

Tabel 2

Distribusi Responden Berdasarkan Usia

\begin{tabular}{lll}
\hline Usia & Frekuensi & Persentase \\
\hline $20-29$ th & 9 & $36 \%$ \\
$30-39$ th & 8 & $32 \%$ \\
$40-49$ th & 8 & $32 \%$ \\
Total & 25 & $100 \%$ \\
\hline
\end{tabular}

Dari data di atas dapat disimpulkan responden dalam penelitian ini dari segi usia cukup merata.

c. Deskripsi responden berdasarkan tingkat pendidikan terakhir

Distribusi responden berdasarkan tingkat pendidikan terakhir dapat dilihat pada Tabel 3 dan disajikan dalam bentuk diagram berikut.

Tabel 3 Distribusi Responden Berdasarkan Tingkat Pendidikan Terakhir

\begin{tabular}{lll}
\hline Pendidikan Terakhir & Frekuensi & Persentase \\
\hline SMA & 1 & $4 \%$ \\
SMK & 1 & $4 \%$ \\
D3 & 1 & $4 \%$ \\
S1 & 20 & $80 \%$ \\
S2 & 2 & $8 \%$ \\
Total & $\mathbf{2 5}$ & $100 \%$ \\
\hline
\end{tabular}


Berdasarkan tabel di atas, responden yang terbanyak adalah responden dengan tingkat pendidikan terakhir sarjana (S1) sebanyak 20 orang dan responden yang terdikit adalah responden dengan tingkat pendidikan terakhir SMA/SMK/D3 sebanyak masing-masing satu orang.

Data ini mengindikasikan bahwa responden dalam penelitian ini adalah mayoritas guru yang sebagian besar telah memenuhi sebagian Standar Kualifikasi Akademik dan Kompetensi Guru pada pendidikan menengah yang mensyaratkan kualifikasi akademik S1 namun belum bisa ditentukan apakah telah sesuai dengan tugas yang diampu.

d. Deskripsi responden berdasarkan tingkat masa kerja

Distribusi responden berdasarkan masa kerja dapat dilihat pada Tabel 4 dan disajikan dalam bentuk diagram berikut.

Tabel 4

Distribusi Responden Berdasarkan Masa Kerja

\begin{tabular}{ll}
\hline Range Masa Kerja & Frekuensi \\
\hline$<3$ th & 12 \\
$3-5$ th & 5 \\
$>5$ th & 8 \\
\hline
\end{tabular}

Berdasarkan tabel di atas, masa kerja responden terbanyak adalah $<3$ tahun sebanyak 12 responden dan yang paling sedikit adalah masa kerja 3-5 tahun.

2. Deskripsi Variabel Penelitian

Deskripsi variabel penelitian bertujuan untuk mengetahui gambaran karakteristik masingmasing variabel penelitian. Analisis deskripsi variabel dilakukan dengan cara statistik deskriptif yaitu menghitung dan menyajikan data kuantitatif tiap variabel yang terdiri dari ukuran tendensi sentral (rata-rata, median), ukuran dispersi (nilai minimum, nilai maksimum, jangkauan, standar deviasi), serta distribusi data (kemiringan (skewness) dan keruncingan (kurtosis)). Hasil analisis statistik deskriptif variabel secara keseluruhan dapat dilihat pada Tabel 5 berikut. 
Tabel 5 Rangkuman Analisis Statistik Deskriptif Variabel

\begin{tabular}{llll}
\hline \multirow{2}{*}{ Statistik Deskriptif } & $\begin{array}{l}\text { Komunikasi } \\
\text { Antarpribadi }\end{array}$ & $\begin{array}{l}\text { Etika Komunikasi } \\
\text { Sekolah }\end{array}$ & $\begin{array}{l}\text { Kepala } \\
\text { Minimum }\end{array}$ \\
Maximum & 20 & 30 & $\begin{array}{l}\text { Loyalitas } \\
\text { Guru }\end{array}$ \\
Mean & 30 & 40 & 43 \\
Std. Deviation & 25.96 & 34.96 & 50 \\
Skewness & 2.937 & 3.348 & 47.88 \\
Std. Error of & -0.14 & 0.349 & 1.833 \\
Skewness & 0.464 & 0.464 & -1.044 \\
Kurtosis & -1.091 & -1.405 & 0.464 \\
Std. Error & 0.902 & 0.902 & 1.051 \\
Kurtosis & & & 0.902 \\
\hline
\end{tabular}

\section{Uji Normalitas}

Uji normalitas dilakukan untuk mengetahui apakah data dari tiap variabel terdistribusi normal atau tidak. Distribusi data yang normal memiliki merupakan syarat yang harus terpenuhi agar bisa melakukan analisis regresi linear. Hasil pengujian normalitas menggunakan metode Kolmogorov-Smirnov Test dengan bantuan piranti lunak SPSS 19.0 (Lampiran 3) ditunjukkan dengan Tabel 6 yang berisi rangkuman output analisis uji normalitas sebagai berikut.

\section{Tabel 6}

\section{Hasil Uji Normalitas}

One-Sample Kolmogorou-Smirnow Test

\begin{tabular}{|c|c|c|}
\hline & & $\begin{array}{l}\text { Unstandardiz } \\
\text { ed Residual }\end{array}$ \\
\hline N & & 25 \\
\hline \multirow[t]{2}{*}{ Normal Parameters ${ }^{a, b}$} & Mean & .0000000 \\
\hline & Std. Deviation & 1.77854932 \\
\hline \multirow[t]{3}{*}{ Most Extreme Differences } & Absolute & .154 \\
\hline & Positive & .074 \\
\hline & Negative & -.154 \\
\hline Kolmogorov-Smirnov $Z$ & & .771 \\
\hline Asymp. Sig. (2-tailed) & & .592 \\
\hline
\end{tabular}

Berdasarkan output pada Tabel 6, nilai signifikansi sebesar 0,592 dimana lebih besar dari 0.05 , sehingga dapat disimpulkan bahwa data tersebut berdistribusi normal.

\section{Uji Hipotesis}

Hasil uji hipotesis penelitian dengan analisis regresi linear ganda dengan menggunakan bantuan piranti lunak SPSS 19.0 akan mendapatkan nilai koefisien determinasi, koefisien regresi, dan uji signifikansinya yang ditunjukkan pada Tabel 7. 
Tabel 7

Hasil Uji Hipotesis

\begin{tabular}{lllll}
\hline $\mathrm{R}$ & 0,242 & & \\
$\mathrm{R}^{2}$ & 0,059 & & \\
\multicolumn{2}{l}{ Signifikansi Regresi } & 0,515 & & \\
Koefisien Regresi & b1 & 0,235 & sig & 0,293 \\
& b2 & $-0,114$ & sig & 0,556 \\
\multirow{2}{*}{ Konstanta } & a & 45,778 & sig & 0,000 \\
\hline
\end{tabular}

Uji signifikansi regresi linear ganda oleh SPSS menunjukkan nilai signifikansi regresi sebesar 0,515 (sig >0,05). Pada uji signifikansi koefisien dan konstanta regresi, didapatkan nilai signifikansi koefisien regresi X1, dan X2 berturut-turut adalah 0,293 dan 0,556 yang semuanya bernilai lebih dari 0,05 (sig>0,05), sedangkan nilai signifikansi konstanta sebesar 0,000 ( sig<0,05). Hasil ini menunjukkan regresi linear ganda signifikan. Kesimpulan dari pengujian hipotesis ini adalah hipotesis nihil diterima, yang berarti komunikasi antarpribadi dan etika komunikasi kepala sekolah secara bersama-sama tidak berpengaruh terhadap loyalitas guru.

Dari Tabel 7 di atas, didapatkan nilai koefisien determinasi antara komunikasi antarpribadi, etika komunikasi kepala sekolah dengan loyalitas guru sebesar 0,059; yang berarti kontribusi komunikasi antarpribadi, etika komunikasi kepala sekolah secara bersamasama terhadap loyalitas guru sebesar 5,9\% selebihnya $(94,1 \%)$ dipengaruhi oleh faktor yang lain.

Persamaan regresi $\mathrm{Y}=\mathrm{a}+\mathrm{b} 1 \mathrm{X} 1+\mathrm{b} 2 \mathrm{X} 2$ dapat diketahui dengan melihat nilai konstanta $(\mathrm{a})=$ 45,778; nilai koefisien regresi komunikasi antarpribadi $(\mathrm{b} 1)=0,225$ dan nilai koefisien regresi etika komunikasi kepala sekolah $(\mathrm{b} 2)=0,339$; sehingga persamaan regresinya adalah $\mathrm{Y}=45,778+0,225 \mathrm{X} 1+0,339 \mathrm{X} 2$. Oleh karena tidak signifikannya kedua koefisien regresi, persamaan regresi tidak dapat digunakan untuk memprediksi. 


\section{Tabulasi Data}

Tabulasi data variabel Komunikasi Antar Pribadi

\begin{tabular}{|c|c|c|c|c|c|c|c|}
\hline \multirow{2}{*}{ No. Resp. } & \multicolumn{6}{|c|}{ Butir Instrumen } & \multirow{2}{*}{ Skor Total } \\
\hline & 1 & 2 & 3 & 4 & 5 & 6 & \\
\hline 1 & 4 & 4 & 3 & 4 & 4 & 4 & 23 \\
\hline 2 & 4 & 4 & 4 & 4 & 5 & 4 & 25 \\
\hline 3 & 5 & 5 & 5 & 5 & 5 & 5 & 30 \\
\hline 4 & 4 & 4 & 4 & 3 & 3 & 4 & 22 \\
\hline 5 & 5 & 5 & 4 & 5 & 5 & 5 & 29 \\
\hline 6 & 3 & 5 & 5 & 5 & 5 & 5 & 28 \\
\hline 7 & 4 & 5 & 5 & 5 & 3 & 4 & 26 \\
\hline 8 & 4 & 4 & & 4 & 4 & 4 & 20 \\
\hline 9 & 5 & 5 & 5 & 5 & 5 & 5 & 30 \\
\hline 10 & 4 & 5 & 5 & 5 & 5 & 5 & 29 \\
\hline 11 & 4 & 4 & 4 & 4 & 5 & 4 & 25 \\
\hline 12 & 4 & 5 & 5 & 5 & 5 & 5 & 29 \\
\hline 13 & 5 & 4 & 4 & 4 & 5 & 5 & 27 \\
\hline 14 & 4 & 5 & 5 & 5 & 5 & 5 & 29 \\
\hline 15 & 5 & 5 & 5 & 5 & 5 & 5 & 30 \\
\hline 16 & 4 & 4 & 4 & 5 & 5 & 4 & 26 \\
\hline 17 & 4 & 4 & 4 & 2 & 4 & 4 & 22 \\
\hline 18 & 4 & 4 & 4 & 4 & 4 & 4 & 24 \\
\hline 19 & 4 & 4 & 4 & 4 & 4 & 4 & 24 \\
\hline 20 & 4 & 4 & 4 & 4 & 4 & 4 & 24 \\
\hline 21 & 4 & 4 & 3 & 4 & 4 & 4 & 23 \\
\hline 22 & 4 & 4 & 4 & 4 & 4 & 4 & 24 \\
\hline 23 & 5 & 5 & 5 & 5 & 5 & 4 & 29 \\
\hline 24 & 5 & 5 & 2 & 5 & 5 & 5 & 27 \\
\hline 25 & 4 & 4 & 4 & 4 & 4 & 4 & 24 \\
\hline
\end{tabular}


B. Tabulasi data variabel Etika Komunikasi Kepala Sekolah

\begin{tabular}{cccccccccc}
\hline & \multicolumn{7}{c}{ Butir Instrumen } & & Skor \\
No. Resp. & & & & & & & Total \\
& 1 & 2 & 3 & 4 & 5 & 6 & 7 & 8 & \\
\hline 1 & 4 & 4 & 4 & 4 & 4 & 4 & 4 & 4 & 32 \\
2 & 5 & 5 & 4 & 5 & 5 & 4 & 5 & 4 & 37 \\
3 & 5 & 5 & 5 & 5 & 5 & 5 & 5 & 5 & 40 \\
4 & 4 & 5 & 3 & 5 & 3 & 4 & 5 & 4 & 33 \\
5 & 5 & 5 & 5 & 5 & 5 & 5 & 5 & 5 & 40 \\
6 & 3 & 5 & 5 & 5 & 5 & 5 & 5 & 5 & 38 \\
7 & 4 & 4 & 4 & 4 & 3 & 5 & 4 & 4 & 32 \\
8 & 4 & 4 & 4 & 4 & 4 & 4 & 4 & 4 & 32 \\
9 & 2 & 5 & 5 & 5 & 5 & 5 & 5 & 5 & 37 \\
10 & 4 & 5 & 5 & 5 & 5 & 5 & 5 & 5 & 39 \\
11 & 4 & 5 & 5 & 4 & 4 & 5 & 4 & 4 & 35 \\
12 & 4 & 5 & 5 & 4 & 4 & 4 & 4 & 4 & 34 \\
13 & 4 & 5 & 4 & 4 & 5 & 5 & 5 & 4 & 36 \\
14 & & 5 & 5 & 5 & 5 & 5 & 5 & 5 & 35 \\
15 & 5 & 5 & 5 & 5 & 5 & 5 & 5 & 5 & 40 \\
16 & 3 & 5 & 4 & 5 & 4 & 4 & 4 & 5 & 34 \\
17 & 4 & 4 & 4 & 4 & 4 & 4 & 4 & 4 & 32 \\
18 & 4 & 4 & 4 & 4 & 4 & 4 & 4 & 4 & 32 \\
19 & 4 & 4 & 4 & 4 & 4 & 4 & 4 & 4 & 32 \\
20 & 4 & 4 & 4 & 4 & 4 & 4 & 4 & 4 & 32 \\
21 & 4 & 4 & 4 & 3 & 4 & 4 & 3 & 4 & 30 \\
22 & 4 & 4 & 3 & 4 & 4 & 4 & 4 & 4 & 31 \\
23 & 5 & 5 & 5 & 5 & 5 & 5 & 5 & 5 & 40 \\
24 & 4 & 5 & 5 & 5 & 5 & 5 & 5 & 5 & 39 \\
25 & 4 & 4 & 4 & 4 & 4 & 4 & 4 & 4 & 32 \\
\hline & & & & & & & & \\
\hline
\end{tabular}


C. Tabulasi data variabel Loyalitas Guru

\begin{tabular}{cccccccccccc}
\hline & & & \multicolumn{7}{c}{ Butir Instrumen } & & \\
No. Resp. & & & & & & & & \\
& 1 & 2 & 3 & 4 & 5 & 6 & 7 & 8 & 9 & 10 & Total \\
\hline 1 & 5 & 5 & 4 & 5 & 5 & 5 & 4 & 5 & 5 & 5 & 48 \\
2 & 5 & 5 & 5 & 5 & 5 & 5 & 5 & 5 & 5 & 5 & 50 \\
3 & 5 & 5 & 4 & 4 & 5 & 5 & 4 & 4 & 5 & 5 & 46 \\
4 & 5 & 4 & 5 & 4 & 5 & 4 & 4 & 4 & 4 & 5 & 44 \\
5 & 5 & 5 & 4 & 5 & 5 & 5 & 5 & 5 & 5 & 5 & 49 \\
6 & 5 & 5 & 5 & 5 & 5 & 5 & 4 & 5 & 5 & 5 & 49 \\
7 & 5 & 5 & 5 & 5 & 5 & 5 & 5 & 5 & 5 & 5 & 50 \\
8 & 5 & 5 & 5 & 5 & 5 & 5 & 5 & 4 & 5 & 5 & 49 \\
9 & 5 & 5 & 4 & 5 & 5 & 5 & 4 & 4 & 5 & 5 & 47 \\
10 & 5 & 5 & 4 & 4 & 5 & 5 & 4 & 4 & 5 & 5 & 46 \\
11 & 5 & 5 & 4 & 5 & 5 & 5 & 4 & 4 & 4 & 5 & 46 \\
12 & 5 & 5 & 5 & 4 & 5 & 5 & 4 & 5 & 5 & 5 & 48 \\
13 & 5 & 5 & 5 & 4 & 5 & 5 & 4 & 4 & 5 & 5 & 47 \\
14 & 5 & 5 & 5 & 4 & 5 & 5 & 5 & 5 & 5 & 5 & 49 \\
15 & 5 & 5 & 5 & 5 & 5 & 5 & 5 & 5 & 5 & 5 & 50 \\
16 & 5 & 5 & 4 & 5 & 5 & 5 & 4 & 5 & 5 & 5 & 48 \\
17 & 4 & 4 & 4 & 4 & 5 & 5 & 4 & 4 & 4 & 5 & 43 \\
18 & 5 & 5 & 5 & 5 & 5 & 5 & 4 & 4 & 5 & 5 & 48 \\
19 & 5 & 5 & 5 & 5 & 5 & 5 & 4 & 4 & 5 & 5 & 48 \\
20 & 5 & 5 & 5 & 5 & 5 & 5 & 4 & 4 & 5 & 5 & 48 \\
21 & 5 & 5 & 5 & 5 & 5 & 5 & 5 & 5 & 5 & 5 & 50 \\
22 & 5 & 5 & 5 & 5 & 5 & 5 & 5 & 4 & 5 & 5 & 49 \\
23 & 5 & 5 & 5 & 5 & 5 & 5 & 5 & 5 & 5 & 5 & 50 \\
24 & 5 & 5 & 4 & 5 & 5 & 5 & 5 & 4 & 5 & 5 & 48 \\
25 & 5 & 5 & 4 & 5 & 5 & 5 & 4 & 4 & 5 & 5 & 47 \\
\hline & & & & & & & & & & &
\end{tabular}


Statistik Deskriptif Variabel

Descriptive Statistics

\begin{tabular}{|c|c|c|c|c|c|c|c|c|c|}
\hline & \multirow{2}{*}{$\begin{array}{c}\mathrm{N} \\
\text { Statisti } \\
\mathrm{C}\end{array}$} & \multirow{2}{*}{$\begin{array}{l}\text { Minimu } \\
\mathrm{m} \\
\text { Statistic }\end{array}$} & \multirow{2}{*}{$\begin{array}{l}\text { Maximu } \\
\mathrm{m}\end{array}$} & \multirow{2}{*}{$\begin{array}{l}\text { Mean } \\
\text { Statisti } \\
\quad \text { c }\end{array}$} & \multirow{2}{*}{$\begin{array}{c}\text { Std. } \\
\text { Deviatio } \\
\mathrm{n} \\
\text { Statistic }\end{array}$} & \multicolumn{2}{|c|}{ Skewness } & \multicolumn{2}{|c|}{ Kurtosis } \\
\hline & & & & & & $\begin{array}{l}\text { Statisti } \\
\text { C }\end{array}$ & $\begin{array}{l}\text { Std. } \\
\text { Erro } \\
r\end{array}$ & $\begin{array}{l}\text { Statisti } \\
\text { C }\end{array}$ & $\begin{array}{l}\text { Std. } \\
\text { Erro } \\
r\end{array}$ \\
\hline $\begin{array}{l}\text { Komunikasi } \\
\text { Antarpribadi }\end{array}$ & 25 & 20 & 30 & 25.96 & 2.937 & -.140 & .464 & -1.091 & .902 \\
\hline $\begin{array}{l}\text { Etika } \\
\text { Komunikasi } \\
\text { Kepala } \\
\text { Sekolah }\end{array}$ & 25 & 30 & 40 & 34.96 & 3.348 & .349 & .464 & -1.405 & .902 \\
\hline $\begin{array}{l}\text { Loyalitas } \\
\text { Guru }\end{array}$ & 25 & 43 & 50 & 47.88 & 1.833 & -1.044 & .464 & 1.051 & .902 \\
\hline $\begin{array}{l}\text { Valid N } \\
\text { (listwise) }\end{array}$ & 25 & & & & & & & & \\
\hline
\end{tabular}

Hasil Perhitungan Uji Normalitas

\section{One-Sample Kolmogorov-Smirnov Test}

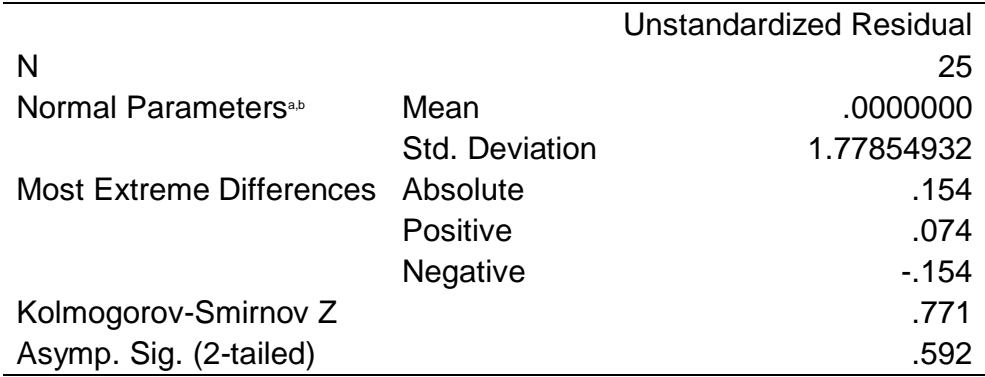
a. Test distribution is Normal.
b. Calculated from data.

\section{Hasil Perhitungan Uji Hipotesis}

\begin{tabular}{llcl}
\hline \multicolumn{2}{l}{ Regression } & \multicolumn{2}{c}{ Variables Entered/Removed } \\
\multicolumn{1}{c}{ Model } \\
1 & \multicolumn{1}{c}{ Variables Entered } & Variables Removed & Method \\
& Antarpribadi & & . Enter \\
\hline
\end{tabular}

a. All requested variables entered.

b. Dependent Variable: Loyalitas Guru

\begin{tabular}{|c|c|c|c|c|c|}
\hline \multicolumn{6}{|c|}{ Model Summary } \\
\hline Model & $\mathrm{R}$ & & R Square & $\begin{array}{l}\text { Adjusted R } \\
\text { Square }\end{array}$ & $\begin{array}{l}\text { Std. Error of } \\
\text { the Estimate }\end{array}$ \\
\hline 1 & & $.242^{\mathrm{a}}$ & .059 & -.027 & 1.858 \\
\hline
\end{tabular}

a. Predictors: (Constant), Etika Komunikasi Kepala Sekolah, Komunikasi

Antarpribadi 


\begin{tabular}{|c|c|c|c|c|c|c|}
\hline \multicolumn{7}{|c|}{ ANOVA $^{b}$} \\
\hline \multicolumn{2}{|c|}{ Model } & $\begin{array}{l}\text { Sum of } \\
\text { Squares }\end{array}$ & df & Mean Square & $\mathrm{F}$ & Sig. \\
\hline \multirow[t]{3}{*}{1} & Regression & 4.722 & 2 & 2.361 & .684 & $.515^{a}$ \\
\hline & Residual & 75.918 & 22 & 3.451 & & \\
\hline & Total & 80.640 & 24 & & & \\
\hline
\end{tabular}

a. Predictors: (Constant), Etika Komunikasi Kepala Sekolah, Komunikasi Antarpribadi

b. Dependent Variable: Loyalitas Guru

\begin{tabular}{|c|c|c|c|c|c|c|}
\hline \multicolumn{7}{|c|}{ Coefficients $^{a}$} \\
\hline \multirow{5}{*}{$\begin{array}{l}\text { Model } \\
1\end{array}$} & & \multicolumn{2}{|c|}{ Unstandardized Coefficients } & $\begin{array}{l}\text { Standardized } \\
\text { Coefficients }\end{array}$ & \multirow[b]{2}{*}{$\mathrm{t}$} & \multirow[b]{2}{*}{ Sig. } \\
\hline & & $\mathrm{B}$ & Std. Error & Beta & & \\
\hline & (Constant) & 45.778 & 3.987 & & 11.482 & .000 \\
\hline & Komunikasi Antarpribadi & .235 & .218 & .376 & 1.077 & .293 \\
\hline & Etika Komunikasi Kepala Sekolah & -.114 & .191 & -.208 & -.597 & .556 \\
\hline
\end{tabular}

a. Dependent Variable: Loyalitas Guru

\section{KESIMPULAN DAN SARAN}

\section{Kesimpulan}

Dari hasil yang didapat dan analisis dari penulis yang dilaksanakan pada guru SMP Maitreyawira Batam pada tahun pelajaran 2015/2016 maka dapat ditarik kesimpulan bahwa komunikasi antarpribadi dan etika komunikasi kepala sekolah tidak berpengaruh terhadap loyalitas guru.

\section{Saran}

Berdasarkan hasil penelitian, maka perlu disampaikan saran-saran sebagai berikut:

1. Untuk penelitian selanjutnya, sampel yang disiapkan diharapkan lebih banyak jumlahnya, selain itu butir-butir instrumen lebih banyak dari penelitian ini.

2. Bagi Kepala SMP Maitreyawira Batam disarankan untuk tetap berkomunikasi dengan etika yang baik, selain itu berkomunikasi antar pribadi tanpa memakai jabatan perlu lebih ditingkatkan sehingga hubungan kekeluargaan akan lebih terasa sehingga meningkatkan kenyamanan dalam bekerja.

\section{REFERENSI}

Arikunto, Suharsimi. 2006. Prosedur Penelitian Suatu Pendekatan Praktik, Jakarta: Rineka Cipta.

Ashrahenny dan Ratnasari, Sri Langgeng. 2016. Pengaruh Gaya Kepemimpinan Dan Komunikasi Terhadap Kinerja Karyawan PT. Hi-Test (Laboratory Of Mechanical Testing). Zona Manajemen ISSN 2087-6998. Fakultas Ekonomi Universitas Batam. Volume 8, Nomor 3, Desember 2016. Hal. 1-10. 
Darmayanti dan Ratnasari, Sri Langgeng. 2016. Pengaruh Gaya Kepemimpinan Dan Fasilitas Kerja Terhadap Kinerja Pegawai Pada Kantor Camat Batam Kota. Zona Manajemen ISSN 2087-6998. Fakultas Ekonomi Universitas Batam. Volume 8, Nomor 1, April 2016. Hal. 11-18

Daryanto, 2001. Administrasi Pendidikan, Jakarta: Rineka Cipta.

Dedi Supriyadi, 1999. Mengangkat Citra dan Martabat Guru.. Yogyakarta: Adicita.

Depdiknas, 2005. Pembinaan Profesionalisme Tenaga pengajar (Pengembangan Profesionalisme Guru). Jakarta: Direktorat Jenderal Pendidikan dasar dan Menengah Direktorat Pendidikan Lanjutan Pertama Depdiknas.

Efendi, Vivi Kusuma dan Ratnasari, Sri Langgeng. 2014. Pengaruh Kepemimpinan, Komunikasi, Dan Motivasi Kerja Terhadap Kinerja Guru SMA Di Kecamatan Batam Kota Batam. Zona Manajemen ISSN 2087-6998. Fakultas Ekonomi Universitas Batam. Volume 6, Nomor 3, Desember 2014. Hal. 1-13

Fatah, N. 1996. Landasan Manajemen Pendidikan. Bandung: Remaja Rosdakarya.

Hasan, M. Iqbal. 2002. Pokok-pokok Materi Metodologi Penelitian dan Aplikasinya, Bogor: Ghalia.

Husein, Umar, 2003. Metodologi Penelitian Untuk Skripsi dan Tesis Bisnis, Jakarta: PT Gramedia Pustaka.

Kountur, Ronny. 2005. Metode Penelitian untuk Penulisan Skripsi dan Tesis, Jakarta: PPM.

Kurnia Aditya, Nina. 2006. Pengaruh Komunikasi Kepemimpinan terhadap Loyalitas Karyawan (Studi Internal Relations pada Operation Departmen PT Badak BGL, Bontang, Kalimantan Timur). Thesis yang dipublikasikan Universitas Muhammadiyah Malang.

Muhammad, A. 2001. Komunikasi Organisasi. Ed. 1, Cet.4 Jakarta: Bumi Aksara.

Lilo, Christianto dan Ratnasari, Sri Langgeng. 2015. Pengaruh Gaya Kepemimpinan Dan Kompensasi Terhadap Kinerja Karyawan Pada PT. Supreme Nusapermai Development. Zona Manajerial. ISSN 2087-7331. Volume 7 Nomor 2, Agustus 2015. Hal. 50-69. Fakultas Ekonomi Universitas Batam

Murwanto, Didik dan Ratnasari, Sri Langgeng. 2016. Pengaruh Kompensasi dan Gaya Kepemimpinan Terhadap Motivasi Kerja Karyawan PT. Fast Precision Manufacturing Indonesia. Zona Manajerial. ISSN 2087-7331. Volume 8 Nomor 1, April 2016. Hal. 1-12. Fakultas Ekonomi Universitas Batam 
Poerwadarminta, W.J.S. 2002. Kamus Umum Bahasa Indonesia. Jakarta: Balai Pustaka.

Ratnasari, Sri Langgeng, Budiman Christiananta, dan Anis Eliyana. 202. Pengaruh Komitmen Organisasional dan Budaya Organisasi Terhadap Kepuasan serta Prestasi Kerja Dosen Tetap Yayasan Perguruan Tinggi Swasta di Provinsi Kepulauan Riau. Jurnal Akuntansi dan Manajemen (JAM) ISSN: 0853-1269, STIE YKPN Yogyakarta, Vol. 23, No.1, April 2012, TERAKREDITASI SK DIRJEN DIKTI NO.:64a/DIKTI/Kep./2010 Tanggal 1 Nopember 2010. Hal 51-60

Robbins dan Judge. 2008. Perilaku Organisasi, Edisi Duabelas, Jakarta: Penerbit Salemba Empat.

Saputro, Andi dan Ratnasari, Sri Langgeng. 2014. Pengaruh Kepemimpinan dan Motivasi Kerja Terhadap Kinerja Karyawan PT. Giken Pricision Indonesia. Zona Manajerial ISSN 2087-7331. Volume 6 Nomor 3, Desember 2014. Fakultas Ekonomi Universitas Batam. Hal. 1-12. 